\title{
APLIKASI ANALISIS SPASIAL DAN STATISTIK MULTIVARIAT TERHADAP KONDISI KUALITAS PERAIRAN DI SELAT ALAS, KABUPATEN SUMBAWA, NUSA TENGGARA TIMUR: ASPEK PENTING UNTUK PENGEMBANGAN BUDIDAYA RUMPUT LAUT
}

\author{
I Nyoman Radiarta, Idil Ardi, dan Anang Hari Kristanto \\ Pusat Penelitian dan Pengembangan Perikanan Budidaya \\ Jl. Ragunan 20, Pasar Minggu, Jakarta Selatan 12540 \\ E-mail: radiarta@yahoo.com
}

(Naskah diterima: 2 Januari 2013; Disetujui publikasi: 8 April 2013)

\begin{abstract}
ABSTRAK
Untuk mendukung pengembangan budidaya rumput laut, pemantauan kualitas perairan secara berkala dan berkelanjutan merupakan satu syarat penting. Analisis spasial dan statistik multivariat telah digunakan dalam penelitian ini untuk mengkaji kondisi kualitas perairan di Selat Alas Kabupaten Sumbawa. Parameter penting kualitas perairan meliputi fisik, kimia, dan biologi perairan telah dikumpulkan dari 32 stasiun. Stasiun pengamatan disebar secara acak sederhana sehingga dapat mewakili lokasi yang disurvai. Hasil analisis menunjukkan bahwa kondisi kualitas perairan masih dalam kategori ideal untuk pengembangan budidaya rumput laut. Analisis statistik multivariat dengan analisis klaster telah membagi kawasan penelitian di Selat Alas menjadi dua kelompok yang berbeda yaitu klaster 1 dan klaster 2 . Klaster 1 merupakan kawasan yang cukup terbuka dan relatif kurang subur. Sedangkan klaster 2 merupakan kawasan yang cukup terlindung dan relatif subur. Klaster 2 ini sangat ideal dimanfaatkan untuk pengembangan budidaya rumput laut. Dengan pendekatan spasial dan analisis klaster ini dapat digunakan untuk merancang pengambilan titik pengamatan di masa yang akan datang sehingga lebih efektif dan efisien.
\end{abstract}

KATA KUNCl: kualitas air, budidaya rumput laut, analisis spasial, Selat Alas, Sumbawa

ABSTRACT: Application of spatial analysis and multivariate statistic to water quality condition in Alas Strait Sumbawa Regency, NTB: an essential aspect for seaweed aquaculture development. By I Nyoman Radiarta, Idil Ardi, and Anang Hari Kristanto

To support the development of seaweed aquaculture, frequent monitoring of water quality is an important factor. Spatial analysis and multivariate statistic shave been used in this study to investigate water quality conditions in Alas Strait, Sumbawa Regency. Important parameters of water quality includes physical, chemical, and biological water shave been collected from 32 sampling stations. These stations were randomly distributed in the study area. The Results show that water quality conditions were still in the ideal category for seaweed aquaculture. Multivariat statistical based on cluster analysis has clasified the study area of Alas Strait into two distinct groups, namely clusters 1 and cluster 2. Cluster 1 was an area that was quite open and relatively poor productivity. Meanwhile cluster 2 was a fairly protected area and relatively productive. Cluster 2 is categorized an ideal area for the development of seaweed aquaculture. With spatial and cluster analysis approaches, it is possible to 
design a future, optimal sampling strategy, which could reduce the number of sampling sites and associated cost.

\section{KEYWORDS: water quality, seaweed aquaculture, spatial analysis, Alas} Strait, Sumbawa

\section{PENDAHULUAN}

Kabupaten Sumbawa merupakan salah satu dari sembilan kabupaten/kota yang berada di Provinsi Nusa Tenggara Barat, dan terletak pada sentral Pulau Sumbawa, yakni pada posisi $116^{\circ} 42^{\prime}-118^{\circ} 22^{\prime}$ Bujur Timur dan 8०8'- $9^{\circ} 7^{\prime}$ Lintang Selatan, dan memiliki luas wilayah $6.643,98 \mathrm{~km}^{2}$ (Anonim, 2010a). Sesuai dengan Keputusan Menteri Kelautan dan Perikanan No. KEP.39/MEN/2011, Kabupaten Sumbawa telah ditetapkan sebagai satu kawasan percontohan minapolitan rumput laut. Penetapan kawasan ini sejalan dengan program pemerintah daerah (pemda) Nusa Tenggara Barat yaitu PIJAR (sapi, jagung, dan rumput laut) yang menetapkan delapan kawasan pengembangan rumput laut di mana dua kawasan berada di Kabupaten Sumbawa yaitu Labuhan Mapin, Kecamatan Alas Barat dan Labuhan Aji, Kecamatan Tarano. Pemda Kabupaten Sumbawa juga telah mengeluarkan regulasi daerah yang mendukung pengembangan kawasan minapolitan di antaranya Keputusan Bupati No. 1315 Tahun 2010 tentang penetapan kawasan minapolitan dan Peraturan Bupati Sumbawa No. 12 tahun 2012 tentang rencana induk kawasan minapolitan Kabupaten Sumbawa. Berdasarkan peraturan tersebut, daerah sentra pengembangan budidaya rumput laut di Kabupaten Sumbawa telah dibagi menjadi enam lokasi pengembangan yaitu: Labuhan Mapin, Pulau Medang, Labuhan Kuris, Labuhan Sangoro, Labuhan Aji, dan Dusun Tanjung Bele Desa Olat Rawa. Produksi rumput laut di Kabupaten Sumbawa menunjukkan peningkatan yang cukup signifikan dari sekitar 10.499 ton pada tahun 2007 menjadi 88.909 ton di tahun 2011 (Anonim, 2010a). Dinas Kelautan dan Perikanan Kabupaten Sumbawa telah mentargetkan peningkatan produksi rumput laut ini sampai tahun 2015 sebesar 575.877 ton (Anonim, 2012). Untuk mendukung peningkatan produksi dan menyediakan informasi mengenai karakterisik lahan, kajian kondisi kualitas perairan perlu dilakukan. Kualitas perairan ini sangat mempengaruhi keberlanjutan usaha budidaya laut, sehingga pengamatan secara berkala perlu dilakukan guna mendukung keberlanjutan usaha budidaya laut (GESAMP, 2001).

Untuk mendukung pengembangan budidaya rumput laut, pemantauan kualitas perairan secara berkala dan berkelanjutan merupakan satu syarat penting. Tujuan utama pemantauan kualitas perairan adalah untuk mengontrol dan meminimalkan dampak yang ditimbulkan dari pencemaran ke dalam perairan sehingga dapat menghasilkan air dengan kualitas standar bagi pengunanya, seperti misalnya perikanan budidaya dan pariwisata (Boyacioglu, 2006). Sehubungan dengan standar kualitas air, Kementerian Negara Lingkungan Hidup telah menetapkan Keputusan Menteri Negara Lingkungan Hidup No. 51 tahun 2004 tentang baku mutu air laut (KLH, 2004). Dasar pertimbangan keputusan ini adalah untuk menjaga kelestarian fungsi lingkungan laut sehingga perlu dilakukan upaya pengendalian terhadap kegiatan yang dapat mencemari dan atau merusak lingkungan laut.

Pemantauan kualitas perairan dapat meliputi parameter fisik, kimia, dan biologi. Untuk menganalisis data kualitas air yang telah dikumpulkan tersebut dapat dilakukan secara geo-spasial ataupun pendekatan statistik (Singh et al., 2004; Ragno et al., 2007). Selain itu, indek kondisi kualitas perairan juga sering digunakan untuk melihat kualitas dari suatu perairan (Simões et al., 2008: Bakan et al., 2010). Analisis yang digunakan tersebut pada umumnya bertujuan untuk memudahkan dalam mengintrepretasikan kumpulan data yang banyak sehingga dapat memberikan informasi yang relevan. Selain itu, dapat memudahkan dalam perancangan pengumpulan data ke depan sehingga dapat meminimalkan biaya dan tenaga yang dikeluarkan.

Tujuan dari penelitian ini adalah untuk menganalisis kondisi kualitas perairan di Selat Alas Kabupaten Sumbawa dengan pendekatan spasial dan statistik mutivariat. Pendekatan analisis spasial dan statistik multivariat ini kemudian dihubungkan dengan pengembangan budidaya rumput laut di lokasi penelitian. Analisis spasial di penelitian ini dilakukan 
dengan menggunakan aplikasi sistem informasi geografis (SIG).

\section{BAHAN DAN METODE}

Penelitian ini telah dilaksanakan di Selat Alas Kabupaten Sumbawa (Gambar 1). Lokasi penelitian terbentang pada posisi $116^{\circ} 51^{\prime}$ $117^{\circ} 6^{\prime}$ Bujur Timur dan $8^{\circ} 23^{\prime}-8^{\circ} 31^{\prime}$ Lintang Selatan. Lokasi penelitian mencakup empat kecamatan yang terbentang dari barat ke timur yaitu: Alas Barat, Alas, Buer, dan Utan. Perairan di lokasi ini cukup terlindung dengan adanya dua pulau penghalang yaitu Pulau Panjang dan Saringi, serta beberapa pulau-pulau kecil lainnya (Gambar 1). Dengan karakteristik perairan tersebut, kawasan ini telah ditetapkan sebagai kawasan minapolitan budidaya rumput laut (Anonim, 2010b; Anonim, 2012). Pengembangan kawasan minapolitan rumput laut di Kabupaten Sumbawa dibagi menjadi tiga wilayah pengembangan sesuai dengan Surat Keputusan Bupati Sumbawa Nomor 1315 Tahun 2010 tentang penetapan kawasan minapolitan rumput laut Kabupaten Sumbawa. Selat Alas masuk dalam kawasan minapolitan Sumbawa bagian barat dengan pusat pertumbuhan (minapolis) di Kecamatan Alas, dan kawasan hinterland-nya meliputi Kecamatan
Alas Barat, Kecamatan Buer, dan Kecamatan Utan (Anonim, 2010b).

Pengumpulan data lapangan dilakukan pada bulan Mei 2012. Metode yang dipakai dalam penelitian ini adalah metode survai yang dirancang berdasarkan SIG. Penentuan lokasi pengamatan dilakukan dengan teknik acak sederhana (simple random sampling) (Clark \& Hosking, 1986; Morain, 1999). Diskusi dengan Dinas Kelautan dan Perikanan digunakan sebagai dasar dalam menentukan sebaran titik pengamatan di lapangan. Sebanyak 32 titik pengamatan kualitas perairan telah berhasil dikumpulkan yang tersebar secara proposional di lokasi penelitian, sehingga dapat mewakili karakteristik wilayah yang disurvai. Setiap titik pengamatan dan pengambilan contoh ditentukan posisi koordinatnya dengan alat GPS (Global Positioning System). Pengukuran kualitas air dan pengambilan contoh air dilakukan pada kisaran waktu pukul 09:0015:00 waktu setempat. Selain pengukuran di permukaan $(<1 \mathrm{~m})$, pengukuran secara stratifikasi (vertikal) juga dilakukan di beberapa titik pengamatan (Gambar 1). Pengukuran secara vertikal dilakukan pada kedalaman yaitu: < 1 m, $5 \mathrm{~m}, 10 \mathrm{~m}, 15 \mathrm{~m}, 20 \mathrm{~m}, 25 \mathrm{~m}$, dan $30 \mathrm{~m}$. Pengukuran secara stratifikasi ini disesuaikan

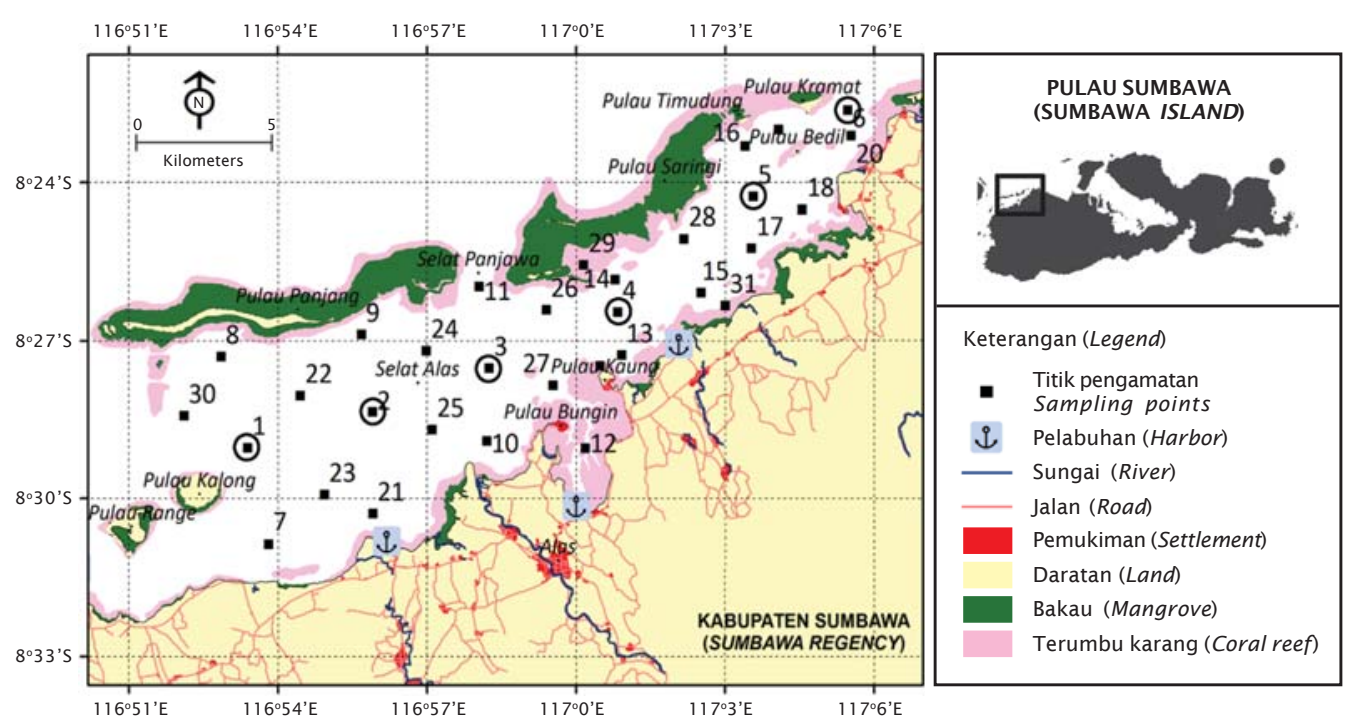

Gambar 1. Karakteristik lokasi penelitian di Selat Alas Kabupaten Sumbawa. Angka di kawasan selat menunjukkan titik pengamatan kualitas perairan. Titik yang dilingkari menunjukkan stasiun pengukuran kualitas air secara vertikal

Figure 1. Characteristic of the study area in Alas Strait, Sumbawa Regency. Numbers inside the study area indicate water quality sampling points. Vertical measurement of water quality indicate by number with the circle 
dengan kedalaman perairan di masing-masing lokasi pengamatan. Data kualitas perairan yang dikumpulkan meliputi: fisik perairan (kedalaman, suhu, kecerahan, dan kecepatan arus), kimia perairan $(\mathrm{pH}$, oksigen terlarut, salinitas, total padatan terlarut, nitrat, amoniak, fosfat, dan sulfat), dan biologi perairan (fitoplankton dan zooplankton). Pengukuran suhu, salinitas, oksigen terlarut, dan $\mathrm{pH}$ dilakukan langsung di lapangan dengan menggunakan YSI 556. Parameter kimia dan biologi lainnya dianalisis di laboratorium Balai Penelitian dan Pengembangan Budidaya Air Payau, Maros. Metode pengambilan, preservasi, dan analisis contoh air mengacu pada metode standar SNI 2004, SNI 2005, dan APHA (1989).

\section{Analisis Biologi}

Kondisi biologi perairan dapat ditentukan atas dasar distribusi plankton. Sampling plankton dilakukan dengan cara menyaring air sebanyak $100 \mathrm{~L}$ menggunakan plankton net berdiameter $25 \mu \mathrm{m}$ dan diawetkan menggunakan larutan lugol $1 \mathrm{~mL} / 100 \mathrm{~mL}$. Perhitungan kelimpahan plankton dilakukan menggunakan alat bantu Sedwick Rafter Counter (SRC) yang dilihat menggunakan alat bantu mikroskop (APHA, 1989). Kelimpahan plankton (fitoplankton dan zooplankton) dihitung dalam individu/L.

Analisis indek ekologi dari data plankton yang meliputi indek dominansi (Simpson's Index (D)), indek kemiripan (Index of Similarity), indek keanekaragaman (Shannon-Wiener Index $(\mathrm{H})$ ), dan indek keseragaman (Evenness (E)) dihitung menggunakan persamaan dalam Odum (1971).

\section{Analisis Spasial}

Kondisi kualitas perairan dianalisis secara spasial yang ditampilkan baik secara horizonal maupun vertikal. Analisis spasial secara horizontal dilakukan dengan teknik inverse distance weighted (IDW) Johnson \& McChow, 2001), yang terdapat dalam perangkat lunak ArcGIS v.10 (The Environmental System Research Institute (ESRI), USA). Sedangkan analisis vertikal menggunakan Ocean Data View (ODV) (Schlitzer, 2011).

\section{Analisis Multivariat Statistik}

Multivariat statistik yang digunakan untuk menganalisis kondisi kualitas perairan di lokasi penelitian adalah analisis klaster (cluster analysis). Cluster analysis (CA) adalah analisis multi- variat yang umumnya digunakan untuk mengelompokkan objek berdasarkan jarak atau kesamaan karakteristik objek yang akan dikelompokkan. CA mengklasifikasikan objek sehingga objek yang serupa akan dikelompokkan dalam klaster yang sama sesuai dengan kriteria yang digunakan (Kazi et al., 2009; Kamble \& Vijay, 2011). Metode CA yang digunakan dalam penelitian ini adalah Hierarchical agglomerative clustering dengan metode Ward (Ward's method) dan squared Euclidean distances untuk mengukur tingkat kesamaan objek. Hasil CA dapat digambarkan dalam bentuk dendogram (diagram pohon). Dendogram ini memberikan informasi visual mengenai proses pengelompokkan, menyajikan gambaran dari kelompok dan kedekatannya, dengan adanya penurunan dimensi dari data aslinya.

Analisis multivariat statistik dalam penelitian ini menggunakan Microsoft Office Excel 2010 dan SPSS 16.0. Seluruh parameter kualitas perairan yang dikumpulkan dalam penelitian ini telah digunakan dalam CA, kecuali pamater kedalaman dan biologi perairan (fitoplankton dan zooplankton).

\section{HASIL DAN BAHASAN}

\section{Kondisi Umum Lokasi Penelitian}

Luas wilayah Kabupaten Sumbawa adalah $10.475,7 \mathrm{~km}^{2}$ meliputi luas daratan $6.643,98$ $\mathrm{km}^{2}$ dan luas perairan laut $3.831,72 \mathrm{~km}^{2}$ (kewenangan kabupaten) dengan panjang pantai sekitar $982 \mathrm{~km}$, dan luas perairan laut termasuk Zona Ekonomi Eksklusif (ZEE) adalah $74.000 \mathrm{~km}^{2}$ (Anonim, 2010a). Jumlah kecamatan di Kabupaten Sumbawa adalah 24 kecamatan di mana 15 kecamatan merupakan kecamatan pesisir (62\%) dengan 54 desa pesisir (35\%) dari keseluruhan 152 desa/ kelurahan di Kabupaten Sumbawa. Sebagian besar wilayah Kabupaten Sumbawa berbukitbukit, akan tetapi sepanjang daerah pesisir khususnya pada bagian barat dan utara umumnya datar sehingga sangat cocok untuk pengembangan perikanan budidaya. Luasnya perairan pesisir dan lautan menjadikan Kabupaten Sumbawa berpeluang dalam mengembangkan potensi pesisir dan lautan untuk berbagai kegiatan perikanan baik penangkapan ikan maupun kegiatan budidaya, yang memberikan kontribusi besar dalam peningkatan pertumbuhan ekonomi dan kesejahteraan masyarakat. 
Perikanan budidaya yang berkembang diantaranya budidaya mutiara, ikan, dan rumput laut. Data penggunaan lahan untuk kegiatan budidaya perikanan terlihat bahwa tingkat pemanfaatannya masih rendah dan mempunyai peluang yang cukup besar untuk dikembangkan (Anonim, 2010b). Kawasan Labuan Mapin (Selat Alas) mempunyai potensi lahan sekitar 3.230 ha, dengan tingkat pemanfaatan baru mencapai 2.582 ha (Anonim, 2011 ). Peningkatan produksi rumput laut di kawasan Selat Alas ini menunjukkan peningkatan yang cukup besar dari 2.000 ton di tahun 2009 menjadi 97.534 ton di tahun 2011 (Anonim, 2011). Peningkatan produksi ini terus diupayakan oleh pemerintah daerah setempat sehingga sesuai dengan target program PIJAR yang dicanangkan oleh pemerintah Provinsi Nusa Tenggara Barat.

\section{Kondisi Kualitas Perairan dan Distribusi Spasial}

Kualitas dari perairan dapat diidentifikasi dari parameter fisik, kimia, dan biologi. Perairan yang tercemar tidak dapat menciptakan eko- sistem yang berimbang. Kondisi ekosistem yang berimbang ini dapat menyediakan lingkungan di mana organisme dapat berinteraksi dengan lingkungan perairan dengan baik. Kondisi perairan memegang peranan penting dalam interaksi ini. Di lokasi penelitian, lahan pesisir yang tersedia telah dimanfaatkan untuk lokasi pengembangan budidaya rumput laut (Kappaphycus alvarezii) dengan metode apung (Anonim, 2011). Ringkasan hasil pengamatan parameter fisik dan kimia perairan ditampilkan pada Tabel 1, yang memberikan informasi tentang kisaran, rataan, dan standar deviasi dari total 32 stasiun pengamatan di Selat Alas Kabupaten Sumbawa. Hasil pengamatan kualitas perairan tersebut kemudian dibandingkan dengan nilai ideal untuk pengembangan budidaya rumput laut. Distribusi spasial dari parameter fisik dan kimia perairan di lokasi penelitian ditampilkan pada Gambar 2.

Kedalaman perairan, suhu, kecerahan, dan kecepatan arus merupakan beberapa parameter penting fisik perairan yang diamati dalam penelitian ini. Nilai dari masing-masing para-

Tabel 1. Hasil pengukuran kualitas perairan di Selat Alas Kabupaten Sumbawa, Nusa Tenggara Barat

Table 1. Range of water quality measurement in Alas Strait Sumbawa Regency, West Nusa Tenggara

\begin{tabular}{lccccc}
\hline \multicolumn{1}{c}{$\begin{array}{c}\text { Peubah } \\
\text { Parameter }\end{array}$} & $\begin{array}{c}\text { Satuan } \\
\text { Unit }\end{array}$ & $\begin{array}{c}\text { Kisaran } \\
\text { Range }\end{array}$ & $\begin{array}{c}\text { Rataan } \\
\text { Average }\end{array}$ & $\begin{array}{c}\text { Standar } \\
\text { deviasi }\end{array}$ & $\begin{array}{c}\text { Nilai ideal } \\
\text { Ideal value }\end{array}$ \\
\hline Fisik perairan (Physical water) & & & & & \\
Kedalaman (Water depth) & $\mathrm{m}$ & $1.1-38.3$ & 18.04 & 8.1 & $3-10$ \\
Suhu air (Water temperature) & ${ }^{\circ} \mathrm{C}$ & $28.6-31.6$ & 29.32 & 0.6 & $28-30$ \\
Kecerahan air (Water tranparency) & $\mathrm{m}$ & $1.1-25$ & 13.09 & 5.6 & 8 \\
Kecepatan arus (Current speed) & $\mathrm{m} / \mathrm{s}$ & $0-0.27$ & 0.14 & 0.09 & $0.2-0.3$ \\
\hline Kimia perairan (Chemical water) & & & & & \\
pH & & $8-8.3$ & 8.17 & 0.03 & $7.5-8.5$ \\
Salinitas (Salinity) & $\mathrm{ppt}$ & $34-35$ & 34.75 & 0.43 & $32-34$ \\
Oksigen terlarut (Dissolved oxygen) & $\mathrm{mg} / \mathrm{L}$ & $3.66-5.76$ & 4.59 & 0.46 & $>5$ \\
Nitrat, $\mathrm{NO}_{3}-\mathrm{N}$ (Nitrate) & $\mathrm{mg} / \mathrm{L}$ & $0.034-0.36$ & 0.11 & 0.07 & $0.1-3.5$ \\
Amoniak, $\mathrm{NH}_{3}-\mathrm{N}$ (Ammonia) & $\mathrm{mg} / \mathrm{L}$ & $0.0045-0.339$ & 0.104 & 0.085 & 0.3 \\
Fosfat, $\mathrm{PO}_{4}-\mathrm{P}$ (Phosphate) & $\mathrm{mg} / \mathrm{L}$ & $0.211-0.821$ & 0.258 & 0.108 & 0.015 \\
Sulfat, SO ${ }_{4}$ (Sulphate) & $\mathrm{mg} / \mathrm{L}$ & $1,659-2,311$ & 1,877 & 141 & - \\
Total padatan terlarut & $\mathrm{mg} / \mathrm{L}$ & $1-85$ & 10.3 & 14.9 & $20-80$ \\
Total suspended solid & & & & & \\
\hline
\end{tabular}

") Tiensongrusmee et al. (1990); Mubarak et al. (1990); KLH (2004) 

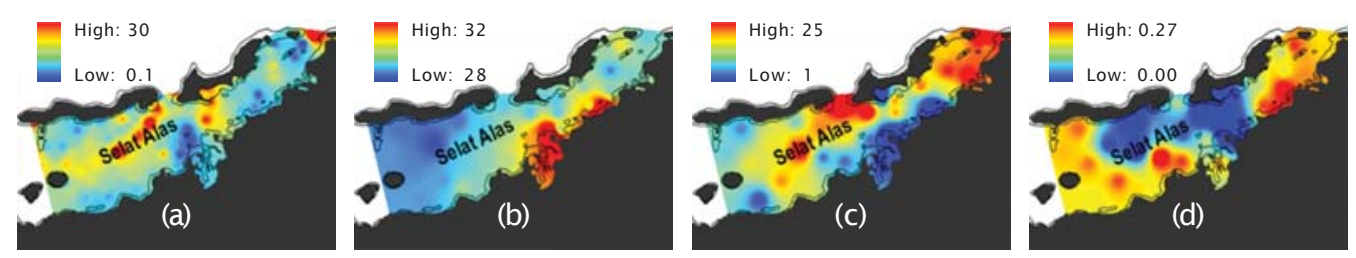

(i) Fisik perairan (Physical water)
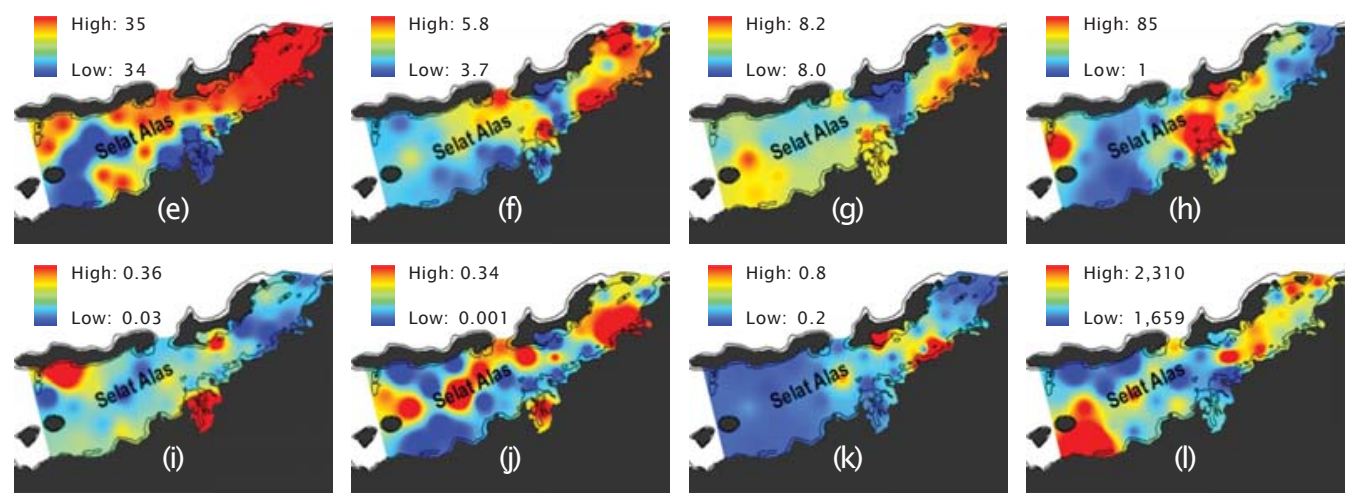

(ii) Kimia perairan (Chemical water)

Gambar 2. Sebaran spasial parameter (i) fisik perairan ((a) kedalaman $(\mathrm{m}),(\mathrm{b})$ suhu perairan $\left({ }^{\circ} \mathrm{C}\right),(\mathrm{c})$ kecerahan (m), (d) kecepatan arus (m/s)) dan (ii) kimia perairan ((e) salinitas (ppt), (f) oksigen terlarut (mg/L), (g) pH, (h) padatan terlarut (mg/L), (i) nitrat (mg/L), (j) amoniak $(\mathrm{mg} / \mathrm{L}),(\mathrm{k})$ fosfat $(\mathrm{mg} / \mathrm{L})$, (I) sulfat (mg/L)) di Selat Alas Kabupaten Sumbawa

Figure 2. Spatial distribution of (i) physical parameters ( $(a)$ water depth $(m),(b)$ water temperature $\left({ }^{\circ} \mathrm{C}\right)$, (c) water transparency $(m),(d)$ current speed) and (ii) chemical parameters ((e) salinity (ppt), ( $f$ ) dissolved oxygen $(\mathrm{mg} / \mathrm{L}),(\mathrm{g}) \mathrm{pH}$, (h) total suspended solid ( $\mathrm{mg} / \mathrm{L})$, (i) nitrate $(\mathrm{mg} / \mathrm{L})$, (j) ammonia $(\mathrm{mg} / \mathrm{L})$, ( $\mathrm{k}$ ) phosphate $(\mathrm{mg} / \mathrm{L})$, (l) sulphate $(\mathrm{mg} / \mathrm{L})$ ) in Alas Strait, Sumbawa Regency

meter fisik perairan jika dibandingkan dengan nilai ideal pengembangan budidaya rumput laut (Tiensongrusmee et al., 1990; Mubarak et al., 1990; KLH, 2004), umumnya masuk dalam kisaran nilai ideal tersebut. Kedalaman perairan berkisar antara 1-38 $\mathrm{m}$. Lokasi dengan kedalaman $>20$ m umumnya terletak di tengahtengah selat antara Pulau Panjang dan daratan Sumbawa (Gambar 2a). Suhu perairan di lokasi penelitian menunjukkan nilai yang ideal untuk pengembangan budidaya rumput laut. Lokasi dengan suhu yang tinggi ditemui di perairan sekitar Pulau Kaung dan Pulau Bungin (Gambar 2b). Kedua pulau tersebut memiliki jumlah penduduk yang sangat padat. Keberadaan penduduk (anthropogenic aspect) tersebut dapat mempengaruhi kondisi kualitas perairan (Wu et al., 2009). Kecerahan perairan memiliki nilai rataan sekitar $13 \mathrm{~m}$. Lokasi dengan tingkat kecerahan tinggi umumnya berasosiasi dengan daerah yang dalam, dan sebaliknya kecerahan rendah umumnya tersebar di dekat pulaupulau yang berpenduduk padat (Gambar 2c). Parameter kecepatan arus masih menunjukkan nilai yang baik untuk pengembangan budidaya rumput laut (Mubarak et al., 1990). Daerah dengan kecepatan arus rendah tersebar merata di tengah Selat Alas (Gambar 2d). Arus yang terlalu rendah $(<0,10 \mathrm{~m} / \mathrm{s})$ tidak sesuai untuk lokasi pengembangan budidaya rumput laut, karena dapat menyebabkan kurangnya nutrien dalam perairan dan dapat mempercepat penempelan sedimen pada rumput laut (Parenrengi et al., 2010). Penempelan sedimen dapat diatasi dengan menggoyang rumput laut secara berkala, namun kurangnya nutrien dapat mempengaruhi tingkat pertumbuhan rumput laut.

Parameter kimia yang diamati dalam penelitian ini meliputi: $\mathrm{pH}$, salinitas, oksigen terlarut (DO), nitrat, amoniak, fosfat, sulfat, dan padatan terlarut (TSS) (Tabel 1). Nilai dari masing-masing 
parameter kimia perairan (kecuali fosfat) menunjukkan masih dalam kisaran baku mutu air laut (KLH, 2004), dan juga ideal bagi pengembangan budidaya rumput laut (Tiensongrusmee et al., 1990; Mubarak et al., 1990). Salinitas berkisar antara 34-35 ppt. Nilai salinitas yang besar umumnya berasosiasi dengan laut terbuka, dan memiliki pola yang berbanding terbalik dengan suhu perairan (Gambar 2b,e). DO memiliki sebaran spasial yang mirip dengan kecerahan perairan (Gambar 2c,f). Konsentrasi DO yang tinggi berasosasi dengan tingkat kecerahan yang tinggi. Nilai kisaran $\mathrm{pH}$ hasil pengamatan menunjukkan kisaran antara 8-8,3. Nilai ini masih ideal untuk pengembangan budidaya laut (ikan dan rumput laut). Nilai pH yang tinggi ditemukan di bagian timur Selat Alas yang berhubungan dengan Laut Flores (Gambar 2g). Konsentrasi TSS yang tinggi (> $50 \mathrm{mg} / \mathrm{L}$ ) umumnya tersebar di perairan dekat dengan pemukiman penduduk (Pulau Bungin dan Pulau Kaung) (Gambar 2h). Tingkat kesuburan perairan yang ditunjukkan melalui parameter nitrat, amoniak, dan fosfat menunjukkan pola sebaran yang sangat bervariasi (Gambar $2 \mathrm{i}-\mathrm{k}$ ). Konsentrasi nitrat dan amoniak yang tinggi juga ditemui di perairan dekat dengan pemukiman penduduk (Gambar $2 \mathrm{i}, \mathrm{j}$ ). Sedangkan konsentrasi fosfat memiliki nilai yang cukup tinggi, diatas batas baku mutu air laut (KLH, 2004), yaitu berkisar antara 0,211$0,821 \mathrm{mg} / \mathrm{L}$.
Untuk mengkaji secara komprehensif kondisi kualitas perairan di lokasi penelitian, dilakukan juga analisis spasial secara vertikal. Vertikal analisis ditampilkan secara membujur (Gambar 3). Sampai pada kedalaman $20 \mathrm{~m}$ terlihat tidak adanya stratifikasi suhu perairan. Suhu air yang lebih hangat terlihat datang dari sisi timur lokasi penelitian (air dari Laut Flores). Sebaran $\mathrm{pH}$ menunjukkan pola yang cukup unik, dengan nilai $\mathrm{pH}$ yang rendah umumnya ditemukan di tengah-tengah lokasi penelitian. Kisaran DO masih di bawah $5 \mathrm{mg} / \mathrm{L}$. Pola sebaran DO secara vertikal terlihat bahwa DO di lapisan atas relatif lebih kecil dari kolom air di bawahnya. Hal ini dapat disebabkan kemungkinan adanya arus bawah yang melintas di lokasi penelitian. Sebaran kualitas perairan secara vertikal ini menjadi penting jika budidaya perikanan yang diterapkan memanfaatkan kolom air yang ada seperti budidaya ikan dengan keramba jaring apung atau budidaya kerang mutiara. Analisis spasial secara vertikal ini dapat memberikan informasi secara menyeluruh terhadap suatu kawasan sehingga dapat membantu dalam pengelolaan suatu kawasan.

Budidaya biota laut selain harus memperhatikan persyaratan kualitas perairan yang telah ditentukan dalam baku mutu air laut untuk biota laut (budidaya perikanan) (KLH, 2004), juga mempunyai persyaratan kualitas air untuk pertumbuhan biota laut yang dibudidayakan sesuai dengan sifat hidupnya
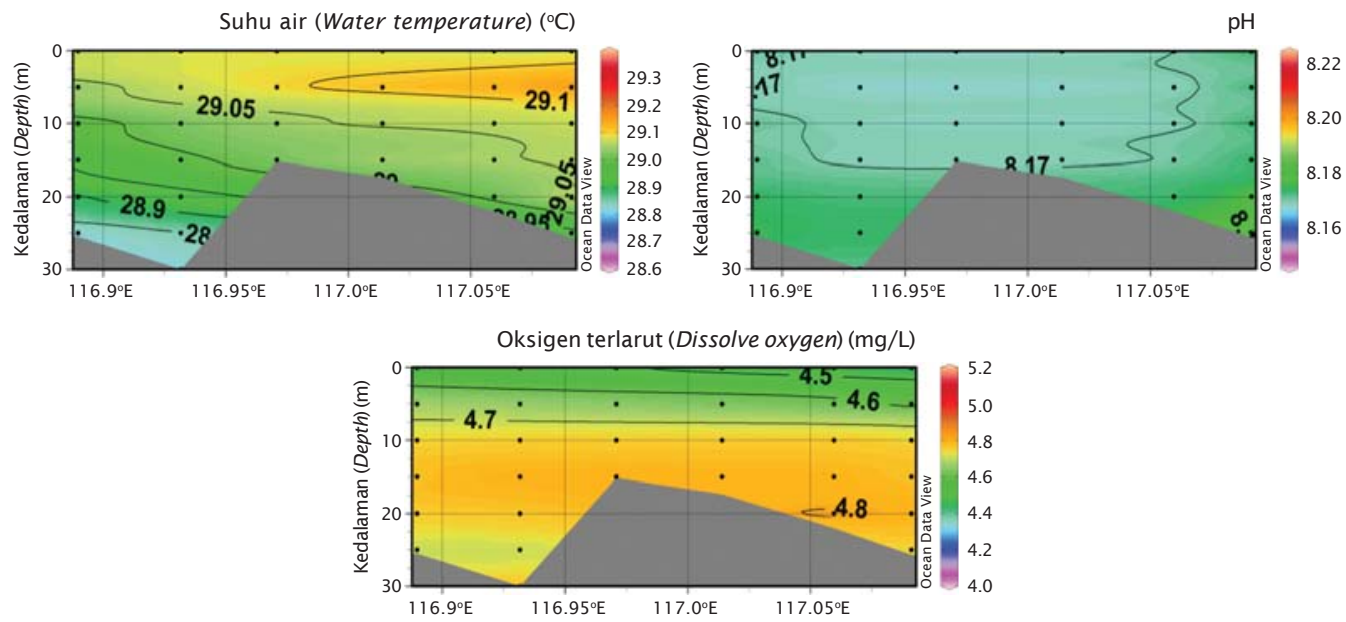

Gambar 3. Distribusi spasial kualitas perairan secara vertikal (stasiun 1-6) di Selat Alas, Kabupaten Sumbawa. Lokasi stasiun dapat dilihat pada Gambar 1

Figure 3. Spatial vertical distribution of water quality (stations 1-6) in Alas Strait, Sumbawa Regency. Stations position show in Figure 1 
(Mubarak et al., 1990; Beveridge, 1996; Sudradjat, 2009). Sehubungan dengan hal tersebut, beberapa kajian telah mengembangkan indek kualitas perairan yang meliputi numerikal (Shuhaimi-othman et al., 2007; Simões et al., 2008; Bakan et al., 2010), statistik (Iscen et al., 2008; Kazi et al., 2009), dan spasial (Pérezet al., 2002), sebagai indikator dari aktivitas perikanan budidaya. Indek yang dikembangkan tersebut umumnya bertujuan untuk melihat kondisi kualitas perairan dan interaksinya dengan aktivitas pemanfaatan lahan perairan (misalnya perikanan budidaya).

\section{Analisis Klaster (Cluster Analysis/CA)}

CA telah diaplikasikan pada kondisi kualitas perairan di Selat Alas dengan tujuan untuk melihat tingkat kesamaan dari masing-masing stasiun pengamatan di seluruh kawasan lokasi penelitian. Hasil dari CA berupa dendogram (Gambar 4), telah mengelompokkan 32 lokasi pengamatan kualitas air menjadi dua kelompok yang berbeda yaitu klaster 1 dengan jumlah stasiun pengamatan sebanyak 12 (stasiun 1 , $2,4,5,6,7,10,11,15,19,24$, dan 28) dan klaster 2 dengan jumlah stasiun pengamatan sebanyak 20 (stasiun 3, 8, 9, 12-14, 16-18, 2023, 25-27, 29-32). Kondisi fisik perairan (suhu air, kecerahan, dan kecepatan arus) dari dua klaster ini secara umum tidak jauh berbeda (Tabel 2). Yang cukup membedakan antara kedua klaster ini adalah parameter kimia perairan terutama nitrat, amoniak, fosfat, sulfat, dan padatan terlarut (Tabel 2).

Berdasarkan karakteristik fisika dan kimia perairan dapat dikatakan bahwa klaster 1 merupakan kawasan perairan yang relatif kurang subur, di mana pengaruh air dari lautan (Laut Flores) mendominasi kawasan tersebut (Gambar 5). Hal ini ditandai dengan rendahnya kandungan nutrien, berupa nitrat yang memiliki rataan $0,08 \mathrm{mg} / \mathrm{L}$. Nilai tersebut masih dibawah baku mutu (KLH, 2004) atupun kondisi ideal untuk budidaya rumput laut (Mubarak et al.,

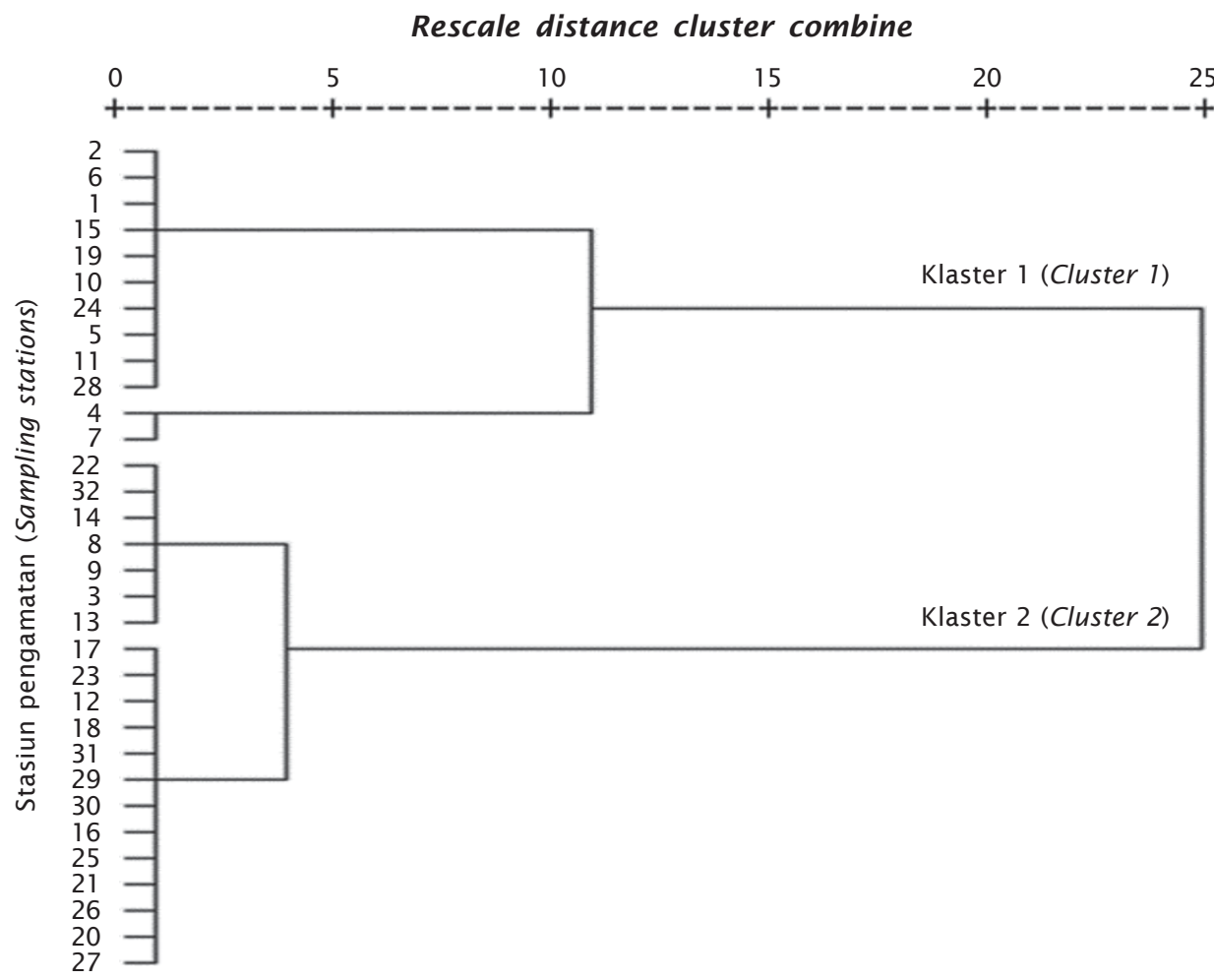

Gambar 4. Dendogram pengelompokkan kawasan perairan berdasarkan kondisi kualitas perairan di Selat Alas Kabupaten Sumbawa, Nusa Tenggara Barat

Figure 4. Dendogram showing clustering of sampling sites according to water quality characteristics in Alas Strait Sumbawa Regency, West Nusa Tenggara 
Tabel 2. Peubah statistik hasil analisis klaster kondisi kualitas perairan di Selat Alas Kabupaten Sumbawa, Nusa Tenggara Barat

Table 2. Statistic parameter for the two defined clusters to water quality condition in Alas Strait Sumbawa Regency, West Nusa Tenggara

\begin{tabular}{|c|c|c|c|c|c|c|c|c|}
\hline \multirow{2}{*}{$\begin{array}{l}\text { Peubah } \\
\text { Parameter }\end{array}$} & \multicolumn{4}{|c|}{ Klaster 1 (Cluster 1$)(\mathrm{N}=12)$} & \multicolumn{4}{|c|}{ Klaster 2 (Cluster 2$)(\mathrm{N}=20)$} \\
\hline & $\begin{array}{l}\text { Rataan } \\
\text { Average I }\end{array}$ & $\begin{array}{l}\text { Minimum N } \\
\text { Minimum } A\end{array}$ & $\begin{array}{l}\text { Maksimum } \\
\text { Maximum }\end{array}$ & SD & $\begin{array}{l}\text { Rataan } \\
\text { Average }\end{array}$ & $\begin{array}{l}\text { Minimum I } \\
\text { Minimum I }\end{array}$ & $\begin{array}{l}\text { Maksimum } \\
\text { Maximum }\end{array}$ & SD \\
\hline \multicolumn{9}{|c|}{ Fisik perairan (Physical water): } \\
\hline $\begin{array}{l}\text { Suhu air } \\
\text { Water temperature }\end{array}$ & 29.15 & 28.91 & 29.53 & 0.21 & 29.42 & 28.69 & 31.64 & 0.79 \\
\hline $\begin{array}{l}\text { Kecerahan air } \\
\text { Water tranparency }\end{array}$ & 15.48 & 7.00 & 25.00 & 5.41 & 11.66 & 1.10 & 21.00 & 5.27 \\
\hline $\begin{array}{l}\text { Kecepatan arus } \\
\text { Current speed }\end{array}$ & 0.15 & 0.00 & 0.22 & 0.07 & 0.13 & 0.00 & 0.28 & 0.10 \\
\hline \multicolumn{9}{|c|}{ Kimia perairan (Chemical water): } \\
\hline Salinitas (Salinity) & 34.67 & 34.00 & 35.00 & 0.49 & 34.80 & 34.00 & 35.00 & 0.41 \\
\hline $\mathrm{pH}$ & 8.18 & 8.15 & 8.20 & 0.01 & 8.16 & 8.03 & 8.19 & 0.04 \\
\hline $\begin{array}{l}\text { Oksigen terlarut } \\
\text { Dissolved oxygen }\end{array}$ & 4.64 & 4.06 & 5.76 & 0.48 & 4.55 & 3.66 & 5.66 & 0.46 \\
\hline Nitrat, $\mathrm{NO}_{3}-\mathrm{N}$ (Nitrate) & 0.08 & 0.04 & 0.11 & 0.02 & 0.12 & 0.03 & 0.36 & 0.08 \\
\hline $\begin{array}{l}\text { Amoniak, } \mathrm{NH}_{3}-\mathrm{N} \\
\text { (Ammonia) }\end{array}$ & 0.13 & 0.01 & 0.34 & 0.09 & 0.07 & 0.00 & 0.24 & 0.08 \\
\hline $\begin{array}{l}\text { Fosfat, } \mathrm{PO}_{4}^{-\mathrm{P}} \\
\text { (Phosphate) }\end{array}$ & 0.23 & 0.22 & 0.24 & 0.01 & 0.27 & 0.21 & 0.82 & 0.14 \\
\hline Sulfat, $\mathrm{SO}_{4}($ Sulphate $)$ & $2,020.08$ & $1,901.35$ & $2,310.70$ & 126.79 & $1,791.08$ & 1,659.6 & $1,868.45$ & 59.12 \\
\hline $\begin{array}{l}\text { Total padatan terlarut } \\
\text { Total suspended solid }\end{array}$ & 6.00 & 2.00 & 18.00 & 4.92 & 12.90 & 1.00 & 85.00 & 18.57 \\
\hline
\end{tabular}

1990). Sedangkan klaster 2 menunjukkan kawasan perairan yang cukup terlindung dan relatif subur (Gambar 5). Konsentrasi nitrat di kawasan ini mempunyai rataan $0,12 \mathrm{mg} / \mathrm{L}$. Nilai ini menunjukkan nilai yang ideal untuk budidaya rumput laut (Mubarak et al., 1990). Kawasan ini banyak mendapat pengaruh dari aktivitas manusia (anthropogenic impact) yang ditandai dengan tingginya padatan terlarut (rataan TSS adalah 12,90 mg/L).

Selain parameter fisik dan kimia perairan, parameter biologi juga dianalisis untuk melihat karakteristik dari masing-masing klaster. Berdasarkan parameter biologi (fitoplankton dan zooplankton), menunjukkan bahwa klaster 2 merupakan kawasan subur yang memiliki kelimpahan dan nilai indek biologi yang umumnya lebih baik dari klaster 1 (Tabel 3).
Beberapa indek biologi yang digunakan dalam penelitian ini meliputi jumlah spesies, indek dominansi, indek kesamaan, indek keanekaragaman, dan indek keseragaman (Tabel 3). Jumlah spesies fitoplankton di klaster 2 lebih banyak dibandingkan klaster 1 , sedangkan jumlah spesies zooplankton di kedua klaster sama. Berdasarkan nilai indek kesamaan (Index of similarity) di kedua klaster menunjukkan nilai indek yang tidak jauh berbeda artinya kondisi distribusi fitoplankton dan zooplankton di perairan Selat Alas masingmasing klaster hampir sama. Adanya kemiripan antar kedua klaster dapat dilihat dari indek keanekaragaman.

Berdasarkan nilai Indek keanekaragaman fitoplankton dan zooplankton di klaster 1 dan 2 masing-masing fitoplankton berkisar 1,69- 


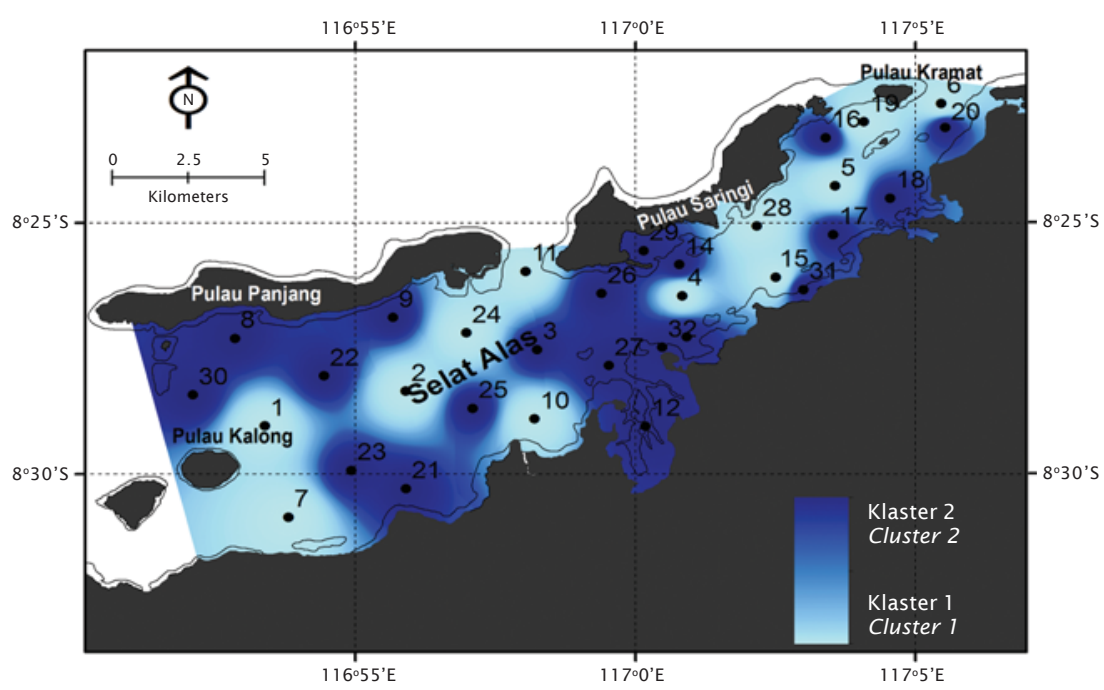

Gambar 5. Peta pengelompokan wilayah perairan berdasarkan analisa klaster kondisi kualitas perairan di Selat Alas Kabupaten Sumbawa

Figure 5. Mapping of water classification based on cluster analysis of water quality in Alas Strait Sumbawa Regency

Tabel 3. Kondisi beberapa indek ekologi penting berdasarkan pengelompokkan wilayah perairan di Selat Alas, Kabupaten Sumbawa, Nusa Tenggara Barat

Table 3. Some important of ecologycal indexes based on the cluster analysis in Alas Strait, Sumbawa Regency, West Nusa Tenggara

\begin{tabular}{|c|c|c|c|c|}
\hline \multirow{2}{*}{$\begin{array}{l}\text { Indek ekologi } \\
\text { Ecology indexes }\end{array}$} & \multicolumn{2}{|c|}{ Klaster 1 (Cluster 1 ) } & \multicolumn{2}{|c|}{ Klaster 2 (Cluster 2) } \\
\hline & Phytoplankt on & Zooplankton & Phytoplankton & Zooplankton \\
\hline $\begin{array}{l}\text { Jumlah spesies } \\
\text { Species richness (S) }\end{array}$ & 15 & 10 & 22 & 10 \\
\hline $\begin{array}{l}\text { Indek dominansi } \\
\text { Simpson's Index (D) }\end{array}$ & 0.293 & 0.295 & 0.311 & 0.31 \\
\hline Index of Similarity (1 - D) & 0.707 & 0.705 & 0.689 & 0.69 \\
\hline Reciprocal index (1/D) & 3,413 & 3.39 & 3,215 & 3,226 \\
\hline $\begin{array}{l}\text { Indek keanekaragaman } \\
\text { Shannon-Wiener Index }(H)\end{array}$ & 1.69 & 1,602 & 1,733 & 1,431 \\
\hline $\begin{array}{l}\text { Indek keseragaman } \\
\text { Evenness (E) }\end{array}$ & 0.624 & 0.696 & 0.561 & 0.621 \\
\hline
\end{tabular}

1,73 dan zooplankton berkisar 1,4-1,6. Nilai indek keanekaragaman di kedua klaster lebih kecil dari 2,30, kondisi ini menunjukkan bahwa fitoplankton dan zooplankton memiliki tingkat keanekaragaman yang rendah. Indeks keanekaragaman dipengaruhi oleh jumlah spesies dan kelimpahan yang bervariasi. Hal ini sesuai dengan pendapat Odum (1971) bahwa me- ratanya kelimpahan spesies yang ada paling berpengaruh terhadap penghitungan indeks keanekaragaman. Hasil identifikasi ditemukan jenis fitoplankton diklaster 1 dan 2 masingmasing berkisar antara 15-22 spesies dan zooplankton hanya 10 spesies. Dengan demikian, fitoplankton dan zooplankton di Selat Alas cenderung terdistribusi secara merata. 
Namun berbeda halnya dengan nilai indek keseragaman. Nilai indek keseragaman fitoplankton dan zooplankton di klaster 1 dan 2 masing-masing fitoplankton berkisar 0,56-0,62 dan zooplankton berkisar 0,62-0,69. Nilai indek keseragaman mendekati satu, dengan demikian fitoplankton dan zooplankton di perairan Selat Alas masing-masing klaster memiliki tingkat keseragaman yang tinggi. Keseragaman plankton di Selat Alas, tidak diikuti dengan tingkat domonasi jenis fitoplankton maupun zooplankton. Nilai indek dominasi di kedua klaster mendekati nol, artinya tidak ada spesies fitoplankton maupun zooplankton yang lebih mendominasi perkembangannya di perairan Selat Alas. Kondisi ini, menunjukkan bahwa tingkat ketersediaan hara di perairan masih dalam kondisi yang tidak berlebihan.

Berdasarkan nilai indek biologi dapat dijelaskan bahwa perairan Selat Alas termasuk perairan yang cukup subur bagi sintasan organime perairan karena adanya kestabilan aliran unsur nutrien. Hasil identifikasi fitoplankton menunjukkan bahwa di klaster 2 spesies fitoplankton lebih beragam dibandingkan dengan spesies fitoplankton yang ada di klaster 1. Selain itu, nutrien juga berasal dari aktivitas antropogenik baik dari pemukiman penduduk maupun kegiatan pertanian yang ada di sekitar Selat Alas.

Berdasarkan karakteristik pembagian wilayah tersebut, dapat dikatakan bahwa untuk kawasan pengembangan budidaya rumput laut, kawasan klaster 2 dapat menjadi prioritas wilayah pengembangan karena didukung oleh kondisi perairan yang lebih subur dan relatif terlindung (Gambar 5).

Hasil pembagian wilayah berdasarkan CA menunjukkan bahwa teknik ini berguna untuk pengelompokkan wilayah pengembangan budidaya laut. Selain itu dengan CA dapat membantu dalam mendisain ataupun menentukan lokasi pengamatan dikemudian hari secara efisien dan efektif sesuai dengan karakteristik perairan untuk seluruh lokasi penelitian sehingga dapat meminimalkan biaya dan tenaga dalam pengumpulan datanya. Aplikasi CA ini juga telah dilakukan oleh beberapa peneliti guna memantau kondisi perairan (laut dan tawar) baik untuk budidaya perikanan (Simões et al., 2008) maupun untuk pemantauan pencemaran perairan (Shrestha and Kazama, 2007; Kazi et al., 2009; Juahir et al., 2011).

\section{KESIMPULAN}

Kondisi kualitas perairan merupakan faktor penting yang perlu dipantau dan diamati secara berkesinambungan, sehingga dampak dari penurunan kualitas perairan terhadap aktivitas pemanfaatan kawasan dapat dicegah sedini mungkin. Dari hasil penelitian ini dapat disimpulkan beberapa hal:

1. Kondisi lingkungan perairan yang meliputi parameter fisik, kimia dan biologi perairan di Selat Alas masih dalam kisaran ideal untuk pengembangan budidaya rumput laut.

2. Hasil CA menunjukkan bahwa kawasan Selat Alas dapat dikelompokkan menjadi dua kawasan (klaster) yang memiliki karakteristik perairan yang berbeda. Klaster 1 merupakan kawasan yang cukup terbuka, dan relatif kurang subur. Sedangkan klaster 2 merupakan kawasan yang cukup terlindung dan memiliki perairan yang subur. Klaster 2 ini sangat ideal dimanfaatkan untuk pengembangan budidaya rumput laut.

\section{UCAPAN TERIMA KASIH}

Penulis mengucapkan terima kasih kepada Dinas Kelautan dan Perikanan Kabupaten Sumbawa atas bantuannya selama kegiatan lapangan. Kami juga mengucapkan terima kasih kepada tim survei minapolitan: Johan Risandi, Makmur, Mat Fahrur, dan Rizky Antoni yang telah membantu kelancaran pengumpulan data lapangan. Penelitian ini merupakan bagian dari penelitian model penerapan dan evaluasi kesesuaian lahan untuk pengembangan minapolitan Pusat Penelitian dan Pengembangan Perikanan Budidaya TA 2012.

\section{DAFTAR ACUAN}

Anonim. 2010a. Profil kelautan dan perikanan Kabupaten Sumbawa. Pemerintah Kabupaten Sumbawa, Dinas Kelautan dan Perikanan, $80 \mathrm{hlm}$.

Anonim. 2010b. Master plan kawasan minapolitan perikanan budidaya Kabupaten Sumbawa. Pemerintah Kabupaten Sumbawa, Dinas Kelautan dan Perikanan, $125 \mathrm{hlm}$.

Anonim. 2011 . Pijar. Evaluasi kegiatan program 2011 \& rencana kinerja tahun 2012. Pemerintah Provinsi Nusa Tenggara Barat, 71 hlm. 
Anonim. 2012. Selayang pandang minapolitan Kabupaten Sumbawa. Dinas Kelautan dan Perikanan Kabupaten Sumbawa, $36 \mathrm{hlm}$.

American Public Health Association (APHA). 1989. Standard Methods for the Examination of Water and Waste Water Including Bottom Sediment and Sludges. $17^{\text {th }}$ ed. Amer. Publ. Health Association Inc., New York, $1527 \mathrm{pp}$.

Bakan, G., Ozkoc, B.H., Tulek, S., \& Cuce, H. 2010. Integrated environmental quality assessment of Kizilirmak River and its coastal environment. Turkish Journal of Fisheries and Aquatic Sciences, 10: 453-462.

Beveridge, M.C.M. 1996. Cage Aquaculture (Eds. $\left.2^{\text {nd }}\right)$. Fishing News Books LTD. Farnham, Surrey, England, 352 pp.

Boyacioglu, H. 2006. Surface water quality assessment using factor analysis. Water S.A., 32(3): 389-393.

Clark, W.A.V. \& Hosking, P.L. 1986. Statistical Methods for Geographers. John Wiley \& Sons, Inc, $513 \mathrm{pp}$.

GESAMP (IMO/FAO/Unesco-IOC/WMO/WHO/ IAEA/UN/UNEP Joint Group of Experts on the Scientific Aspects of Marine Environmental Protection). 2001. Planning and management for sustainable coastal aquaculture development. FAO Rep. Stud. GESAMP No. 68: 90 pp.

Iscen, C.F., Emiroglu, O., Ilhan, S., Arslan, N., Yilmaz, V., \& Ahiska, S. 2008. Application of multivariate statistical techniques in the assessment of surface water quality in Uluabat Lake, Turkey. Environmental Monitoring Assessment, 144: 269-276.

Johnson, K. \& McChow, J. 2001. Using ArcGIS spatial analysis. Environmental Systems Research Institute (ESRI), Inc, USA, 236 pp.

Juahir, H., Zain, S.M., Yusoff, M.K., Hanidza, T.I.T., Armi, A.S.M., Toriman, M.E., \& Mokhtar, M. 2011. Spatial water quality asessment of Langat River Basin (Malaysia) using environmentric techniques. Enviroment Monitoring Assessment, 173: 625-641.

Kamble, S.R. \& Vijay, R. 2011 . Assessment of water quality using cluster analysis in coastal region of Mumbai, India. Environ. Monit. Assess., 178: 321-332.

Kazi, T.G., Arain , M.B., Jamali, M.K., Jalbani, N., Afridi, H.I., Sarfraz, R.A., Baig, J.A., \& Shah, A.Q. 2009. Assessment of water quality polluted lake using multivariate statistical technique: a case study. Ecotoxixology and Environmental Safety, 72: 301-309.
KLH [Kementerian Lingkungan Hidup]. 2004. Keputusan Menteri Negara Kependudukan dan Lingkungan Hidup No. 51 tahun 2004, tanggal 8 April 2004 tentang baku mutu air laut. Kementerian Lingkungan Hidup. Jakarta, $11 \mathrm{hlm}$.

Morain, S. 1999. GIS solution in natural resources management: balancing the technical-political equation. On world press. USA, $361 \mathrm{pp}$.

Mubarak, H., Ilyas, S., Ismail, W., Wahyuni, I.S., Hartati, S.H., Pratiwi, E., Jangkaru, Z., \& Arifuddin, R. 1990. Petunjuk teknis budidaya rumput laut. Badan Litbang Pertanian, Puslitbang Perikanan. IDRC, Infish, $93 \mathrm{hlm}$.

Odum, E.P. 1971. Fundamentals of Ecology. Third edition. W.B. Saunders Company, Philadelphia, London, Toronto, 574 pp.

Parenrengi, A., Rachmansyah, \& Suryati, E. 2010. Budidaya Rumput Laut Penghasil Karaginan (Karaginofit). Balai Riset Perikanan Budidaya Air Payau, Badan Penelitian dan Pengembangan Kelautan dan Perikanan, Kementerian Kelautan dan Perikanan, Jakarta, 54 hlm.

Pérez, O.M., Telfer, T.C., Beveridge, M.C.M., \& Ross, L.G., 2002. Geographical information systems (GIS) as a simple tool to aid modelling of particulate waste distribution at marine fish cage sites. Estuarine, Coastal and Shelf Science, 54: 761-768.

Ragno, G., De Luca, M., \& loele, G. 2007. An application of cluster analysis and multivariate classification methods to spring water monitoring data. Mathematical Journal, 87: 119-127.

Schlitzer, R. 2011 . Ocean Data View. WWW Page. http://odv.awi.de.

Shrestha, S. \& Kazama, F. 2007. Assessment of surface water quality using multivariate statistical techniques: A case study of the Fuji river basin; Japan. Environmental Modelling \& Software, 22: 464-475.

Shuhaimi-othman, M., Lim, E.C., \& Mushrifah, I. 2007. Water quality changes in Chini Lake, Pahang, West Malaysia. Environmental Monitoring Assessment, 131: 279-292.

Singh, K.P., Malik, A., Mohan, D., \& Sinha, S. 2004. Multivariate statistical techniques for the evaluation of spatial and temporal variations in water quality of Gomti river (India): a case study. Water Res., 38: 3,980-3,992.

Simões, F.S., Moreira. A.B., Bisinoti, M.C., Gimenez, S.M.N., \& Yabe, M.J.S. 2008. Water quality index as a simple indicator of 
aquaculture effects on aquatic bodies. Ecological Indicators, 8: 476-484.

Sudradjat, A. 2009. Budidaya 23 komoditas laut menguntungkan. Cetakan ke 2. Penebar Swadaya, Jakarta, $172 \mathrm{hlm}$.

Tiensongrusmee, B. 1990. Site selection for Eucheuma spp. farming. UNDP/FAO Regional Seafarming Development and Demonstration Project (RAS/90/002). Kasetsart University Campus, Bangkok, Thailand. http://www.fao.org/docrep/field/003/ AB738E/AB738E00.htm\#TOC disadur tanggal 30 November 2010.

Wu, M-L., Wang, Y-S, Sun, C-C, Wang, H., Dong, JD, \& Han, S-H. 2009. Identifikation of antropogenic effects on seasonality on water quality in Daya Bay, South China Sea. Journal of Environmental Management, 90: 3,082-3,090. 